\title{
Network Optimization of Packaging Water Factory "Aeta" by Using Critical Path Method (CPM) in Tirta Taman Sari Drinking Water Company, Madiun City
}

\author{
Faiz Ainur Razi ${ }^{1}$, Wanda Wira Yudiarti ${ }^{2}$ \\ ${ }^{1}$ Mathematics, State University of Surabaya, e-mail : faizainurrazi9c@gmail.com \\ ${ }^{2}$ Mathematics, Brawijaya University, e-mail : ndanda.yudiarti@gmail.com
}

\begin{tabular}{|c|}
\hline $\begin{array}{l}\text { Article history: } \\
\text { Received : 11-08-2020 } \\
\text { Revised : 30-08-2020 } \\
\text { Accepted : 03-09-2020 }\end{array}$ \\
\hline $\begin{array}{l}\text { Keywords: } \\
\text { Critical Path Methods; } \\
\text { Networking; } \\
\text { Project Management; } \\
\text { Optimization; } \\
\text { Aeta }\end{array}$ \\
\hline 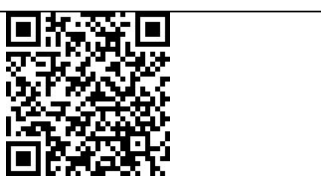 \\
\hline
\end{tabular}

\begin{abstract}
Project management is a new thing with the development of two analytical techniques used for planning, scheduling, and decision making on projects to be carried out so that they can be carried out optimally and efficiently. These two analytical techniques are the Critical Path Method (CPM) and Project Evaluation and Review Technique (PERT). Network optimization for the project is very important for the production of with "Aeta" brand Bottled Mineral Water produced by drinking water company in Madiun. This optimization is carried out in order to find out the production schedule of bottled water, there are 4 packages produced namely cups, $1.5 \mathrm{~L}$ bottles, $600 \mathrm{ml}$ bottles, and gallons. After scheduling using the Critical Path Method, ie bottled water production will be more profitable if more products are in Gallon packaging. Because the Gallon packaging will save time this happens because the Gallon packaging does not go through cardboard packaging.
\end{abstract}

ABSTRACT

This is an open access article under the CC BY-SA license.

DOI: https://doi.org/10.30812/varian.v4i1.834

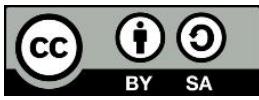

\section{A. INTRODUCTION}

The wealth of natural resources owned by Indonesia is very abundant, including the wealth of water. This is certainly not surprising considering the vast forest area that covers Indonesia, especially those around the mountains where the water source feels like it will never stop flowing. Likewise with the wealth of water in Madiun City. This city has an area of $33.23 \mathrm{~km} 2$ and is geographically located between mountainous areas, making this city has abundant water resources. Two mountains in this city are Mount Wilis and Mount Lawu which store water resources. It is common knowledge that water is important in all things, one of which is for health. A safe, reliable, affordable, and easily accessible water source is a basic necessity for health (Hunter, MacDonald, \& Carter, 2010). Without water, life on this earth would not exist either. Water is present in every cell of the human body and acts as a building material. This function is what makes water play a very important role and is also beneficial for the growth period of the human body. (Jéquier \& Constant, 2010).

Therefore, the primary thing to determine the quality of human life is the presence of quality clean water. In addition, water is also needed for various activities so that all can run well. Water is the main constituent of the human body because about $60 \%$ of our body weight consists of water. This water content varies with the composition of the human body. As population increases and economic development escalates, the economic and social functions of water are often disrupted due to increasingly critical water 
supplies, while water demand continues to increase. Thus, if water cannot meet human needs, human activities can be disrupted.

Judging from the abundance of water wealth in Madiun City, the Tirta Taman Sari Regional Drinking Water Company (PDAM) provides facilities for the community to enjoy high quality clean water. In addition to the main product in the form of water distribution to the community, this PDAM also provides another product in the form of Bottled Drinking Water (AMDK). The product is in the form of a cup (glass packaging) with the name AETA. Bottled drinking water produced by this factory has bottles of $250 \mathrm{ml}, 1$ litre and refill gallons. Every production requires a working system that is well controlled so that the economic concept can be achieved. One of them is to spend less but can get many benefits.

The PERT / CPM method is a powerful technique for dealing with various problems (Kopanos, Kyriakidis, \& Georgiadis, 2014; Kyriakidis, Kopanos, \& Georgiadis, 2012). Without water, life on this earth would not exist either. Water is present in every cell of the human body and acts as a building material. This function is what makes water play a very important role and is also beneficial for the growth period of the human body. (Jéquier \& Constant, 2010). Therefore, the primary thing to determine the quality of human life is the presence of quality clean water. In addition, water is also needed for various activities so that all can run well.

Water is the main constituent of the human body because about $60 \%$ of our body weight consists of water. This water content varies with the composition of the human body. As population increases and economic development escalates, the economic and social functions of water are often disrupted due to increasingly critical water supplies, while water demand continues to increase. Thus, if water cannot meet human needs, human activities can be disrupted.

Judging from the abundance of water wealth in Madiun City, the Tirta Taman Sari Regional Drinking Water Company (PDAM) provides facilities for the community to enjoy high quality clean water. In addition to the main product in the form of water distribution to the community, this PDAM also provides another product in the form of Bottled Drinking Water (AMDK). The product is in the form of a cup (glass packaging) with the name AETA. Bottled drinking water produced by this factory has bottles of $250 \mathrm{ml}, 1$ litre and refill gallons. Every production requires a working system that is well controlled so that the economic concept can be achieved. One of them is to spend less but can get many benefits.

The PERT / CPM method is a powerful technique for dealing with various problems (Takakura, Yajima, Kawajiri, \& Hashizume, 2019). The purpose of this CPM is to identify activity on the critical path so that the time used can be maximized (Shankar, Sireesha, \& Rao, 2010). Related to this, in optimizing industrial processes in the field of drinking water packaging, the authors use CPM. This method is used to obtain optimal work networks so that maximum benefits can be obtained in the industrial world.

\section{B. LITERATURE REVIEW}

The critical path method (CPM) is a step-by-step project management technique for process planning that defines critical and non-critical tasks with the goal of preventing time-frame problems and process bottlenecks ((Zareei, 2018). The critical path method (CPM) is an optimal research technique of analysis to find the critical path, i.e., the sequence of activities with the minimum energy in wireless sensor node. CPM uses activity oriented network estimate with fair degree of accuracy and control both time and energy in network (Pankaj, Kumar, \& Agarwal, 2020). The critical path method (CPM) is a systematic approach for allocating resources among activities to reduce project duration for the least cost (Nicholas \& Steyn, 2020).

The project's CPM schedule is the best tool to use to identify and measure critical project delays. This is because the project CPM schedule (Nagata, Manginelli, Lowe, \& Trauner, 2018):

1. Shows the contractor's plan to complete the project

2. Captures the alterations to the contractor's plan

3. Forecasts when the project will finish 
Most construction contracts recognize this fact and require the contractor to perform a schedule analysis using the project schedule to measure the project delay when requesting a time extension. In applying the CPM, there are several steps that can be summarized ((Zareei, 2018):

1. Define the required tasks and put them down in an orderly sequenced list Create a flowchart or other diagram showing each task in relation to the others.

2. Identify the critical and noncritical relationships (paths) among tasks.

3. Determine the expected completion or execution time for each task

4. Locate or devise alternatives (backups) for the most critical paths.

5. Calculate the duration for each path, and chart out the activities considering the dependencies and then identify the longest path.

6. Construct the network diagram.

7. Compute the path time for each path as the sum of individual activities of the path. The path having the longest time is the critical path and each activity in this path is the critical activity.

8. The other paths normally take less time, so they have some "slack," meaning you can delay or slow them in order to concentrate on the critical path.

9. This would enable identifying those activities whose durations can be reduced by

a. analyzing like method study and brainstorming

b. by shifting more resources toward the completion of that activity

c. increasing the speed of execution of that activity

This reduction of activity time is called crash duration. The application of the value engineering method is best to be done in the early stages of the construction project, optimally in the planning phase in order saving that is corresponding to the main goal of the VE (Value Engineering) it self which is to increase the overall project performance and efficiency (S.-P. Chen, 2007).

\section{RESEARCH METHOD}

Optimal control is a branch of science that is very important in determining the schedule of an activity (project scheduling), including the Critical Path Method (CPM). The CPM method is used by most project managers to identify critical activities and calculate the minimum time required for project completion (Zareei, 2018). This method can be applied to get solutions to various problems and in large-scale project programming (Mazlum \& Güneri, 2015). Through the use of this method, it is hoped that the management of a product operation can be more efficient. The advantage of the CPM scheduling method when compared to bar charts is that it can show complete activity details as well as the relationship between activities (Ahmed, 2018).

The data taken in this study are based on observations made at the Tirta Taman Sari Regional Drinking Water Company (PDAM), Madiun City, especially during the processing of water products in AETA packaging. The data obtained is then processed to obtain optimal results in terms of time management when processing bottled drinking water, which includes drinking water packaged in cups, bottles or gallons.

\section{Critical and Dummy Paths}

The critical path is a path in a network that has a series of activity components with the longest total time and the fastest project completion time. The critical path has three special characteristics, where these three features can be used as a reference to find out how the optimal network is. The following are characteristics of critical pathways.

a. The path that takes the longest in a process.

b. The path with a time tension between the completion of an activity stage and the start of a later activity stage.

c. The absence of this time tension is the critical nature of the critical path.

Dummy is an activity that has no implementation time and is only needed to show activities with predecessor activities. Dummy is needed to illustrate that there is a relationship between activities. Given 
that the dummy is a pseudo activity, so the duration of the dummy activity is zero. In this case, the dummy consists of two types, namely:

a. Grammatical Dummy

Grammatical dummy is needed to avoid confusion over the mention of activity if there are two or more activities originating from the same event (eg i) and ending in the same event (eg j). Grammatical dummy will make it easier for computers to distinguish activities from one another.

b. Logical Dummy

Logical dummy is logic that has no effect on scheduling calculations. However, it can be necessary to identify certain activities (Nagata et al., 2018). In other words, the logical dummy is used to describe the relationship between activitie.

\section{Determination of Time}

In calculating the timing for the network during production, there are several assumptions used, namely as follows ((Zareei, 2018):

a. The project has only one initial event and one terminal event

b. The fastest time for the initial event to occur is day zero

c. The time of the latest terminal event occurs is $\mathrm{TL}=\mathrm{TE}$ for events

The method of calculation that must be done consists of two ways, namely forward computation and backward computation(Wang et al., 2005). In the forward calculation, the calculation will move from the initial event to the terminal event. While in the backward computation, the calculation will move from the terminal event to the initial event. This step is taken to calculate the fastest or the slowest time in each activity. After these two steps are carried out, a float (elasticity) will be obtained (K. Chen et al., 2015; Sahoo \& Ray, 2020).

\section{Forward Calculation}

The earliest start and finish times for each activity are calculated based on forwarding calculations (Zareei, 2018). There are three steps carried out in forwarding calculations, namely:

a. The fastest time for the initial event to occur is determined on the zero-day so that the initial event applies TE $=0$.

b. If the initial event occurs on day zero, so $\mathrm{TE}=0$

c. The event that combines several activities (merge event), so the maximum value of the total EF should be searched.

\section{Backward Calculation}

The backward calculation, in this case, has the same steps as for the forward calculation. However, the applicable terminal event is TL = TE. Each activity can only be started if the event that preceded it has occurred. Therefore, the slowest time an event occurs is equal to the smallest value of the slowest moments. The formula used to find the final value of the backward calculation is an equation (1):

$$
\mathrm{TL}_{(\mathrm{i})}=\min \left(\mathrm{LS}_{(\mathrm{i}, \mathrm{j} 1)}, \mathrm{LS}_{\left.(\mathrm{i}, j 2), \ldots, L S_{(\mathrm{i}, \mathrm{j})}\right)}\right.
$$

\section{Calculation of Allowance Time (Float or Slack)}

After the forward and backward calculations have been carried out, the next step that must be done is to calculate the allowance (float/slack) which consists of total float and free float. The total float is the amount of time that the completion time of an activity can be postponed without affecting the quickest time of completion of the overall project. Meanwhile, free float is the amount of time that the completion of an activity can be measured without affecting the fastest time from starting other activities (Susana, 2003). Calculations to determine the critical trajectory can be summarized in a table that contains all the information needed to create an implementation time-chart (S.-P. Chen, 2007; Ubar, Kostin, Jenihhin, Raik, \& Jürimägi, 2018) 


\section{RESULTS AND DISCUSSION}

Scheduling a project is important in the management of an activity. If the data and models used are correct, the results of the project scheduling will be more effective. This section will explain the results of the scheduling that has been done. The flowchart obtained from the company in this study is as Figure 1:

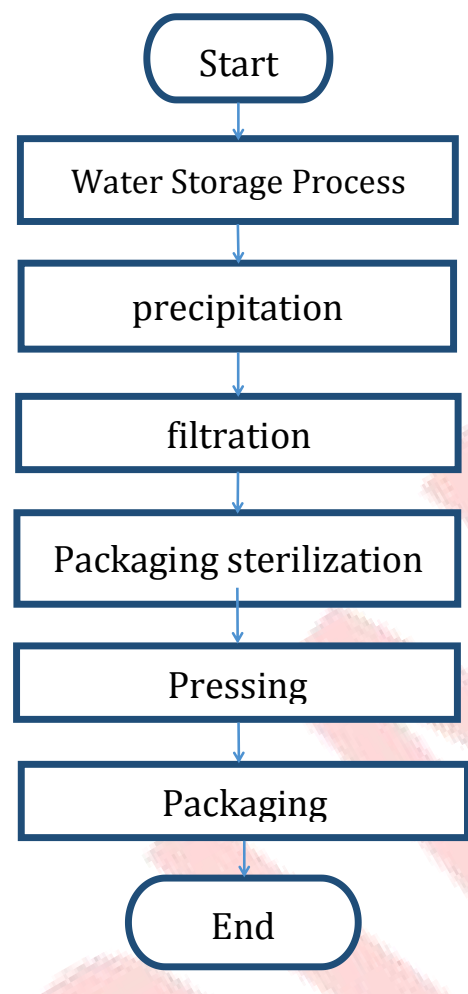

Figure 1. Flowchart Network Without Modification

In accordance with the flowchart in Figure 1, activities are carried out linearly, causing inefficient time accumulation. A job that should be done more quickly, but if there are no time savings it will also cost a lot. Moreover, the products issued by the bottled drinking water company AETA are not small. There are 4 products produced by industrial activities in this factory, namely drinking water with cup packaging, $1.5 \mathrm{~L}$ drinking water packaging, $600 \mathrm{ml}$ drinking water bottles packaging, and gallons. The flowchart is modified so that a new model is obtained. This new model was used to determine the optimal time for the activities to be carried out. Here is a new model of the packaging process for drinking water products with a critical path:

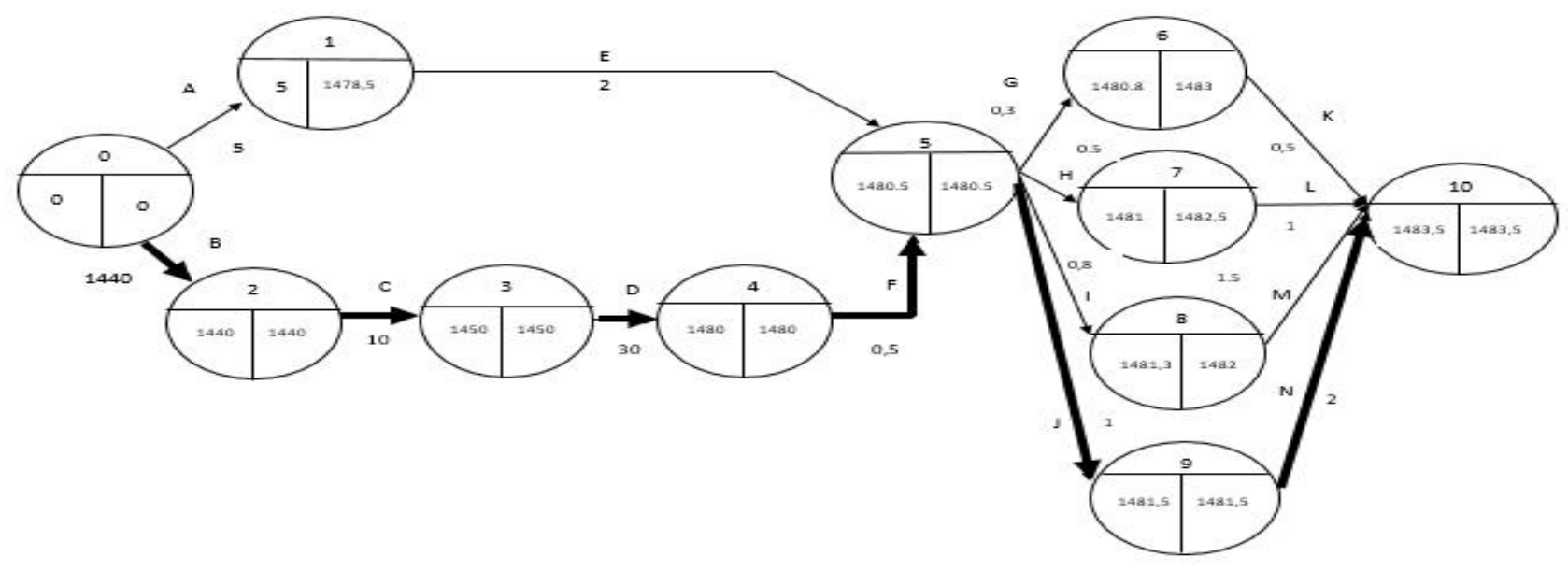

Figure 2. Network Diagram with Critical Path 
From Figure 2, the time required for activity $\mathrm{A}$ is 5 minutes so that the fastest time for activity $\mathrm{A}$ is in the fifth minute or $\mathrm{EF}_{(0,1)}=5$. Because activity $\mathrm{A}$ is the only one that enters node 1, the fastest time for node 1 event to occur is also the fifth day or $\mathrm{TE}_{(1)}=5$, as well as other activities.

If the activity leading to a node is linear, then $E F=T E+t(i, j)$. However, if the form of a network is a merge event (several activities), then TE (j) = max (EF (i1, j), EF (i2, j), ..., EF (in, j). As in the example TE (5), we can find $\mathrm{EF}_{(1,5)}=1+2=3$ and $\mathrm{EF}_{(4,5)}=1480,5$ so that $\mathrm{TE}_{(5)}=\max (3 ; 1480,5)=1480,5$. the last value, $\mathrm{TE}$ ${ }_{(10)}=\max (1480.8+0.5 ; 1481+1 ; 1481.3+1.5 ; 1481.5+2)=1483.5$.

The method used to calculate the value of the linear node computation is the same as finding the value in the forward time calculation. However, the time in TL is the difference from LF-t. For example, at $\mathrm{TL}_{(9)}=$ 1483.5-2 $=1481.5$, then $\mathrm{TL}_{(9)}$ is worth 1481.5. Meanwhile, to find the terminal event from countdown time calculation, then $\mathrm{TL}(0)=\min (1440-1440,1478,5-5)=0$.Calculations to determine the critical path can be summarized in a table that contains all the information needed to create an implementation time chart. The table of the network model is shown in Table 1.

Table 1. List of Activities in Scheduling Aeta Product Packaging Using CPM Method

\begin{tabular}{|c|c|c|c|c|c|c|c|}
\hline \multirow{2}{*}{$\begin{array}{l}\text { Description of } \\
\text { activities }\end{array}$} & \multirow{2}{*}{$\begin{array}{l}\text { Duration } \\
\text { (Minute) }\end{array}$} & \multicolumn{2}{|c|}{ The fastest one } & \multicolumn{2}{|c|}{ The slowest one } & \multirow{2}{*}{$\begin{array}{l}\text { Total } \\
\text { Float }\end{array}$} & \multirow{2}{*}{$\begin{array}{l}\text { Free } \\
\text { Float }\end{array}$} \\
\hline & & $\begin{array}{c}\text { Start } \\
\text { ES }\end{array}$ & $\begin{array}{c}\text { Done } \\
\text { EF }\end{array}$ & $\begin{array}{c}\text { Start } \\
\text { LS }\end{array}$ & \begin{tabular}{|c|} 
Done \\
LF
\end{tabular} & & \\
\hline $\begin{array}{l}\text { Packaging } \\
\text { Sterilization (A) }\end{array}$ & 5 & 0 & 5 & 0 & 1478,5 & 1473 & 0 \\
\hline $\begin{array}{l}\text { Water storage } \\
\text { process (B) }\end{array}$ & 1440 & 0 & 1440 & 0 & 1440 & 0 & $\left.0^{*}\right)$ \\
\hline Precipitation (C) & 10 & 1440 & 1450 & 1440 & 1450 & 0 & $\left.0^{*}\right)$ \\
\hline Filtration (D) & 2 & 5 & 1480,5 & 1478,5 & 1480,5 & 1473,5 & 14735 \\
\hline $\begin{array}{l}\text { Press Preparation } \\
\text { (E) }\end{array}$ & 30 & 1450 & 1480 & 1450 & 1480 & 0 & $\left.0^{*}\right)$ \\
\hline $\begin{array}{l}\text { Packaging } \\
\text { Preparation (F) }\end{array}$ & 0,5 & 1480 & 1480,5 & 1480 & 1480,5 & 0 & $\left.0^{*}\right)$ \\
\hline Cup Pressing (G) & 0,3 & 1480,5 & 1480,8 & 1480,5 & 1483 & 2,2 & 0 \\
\hline $\begin{array}{l}\text { Bottle Pressing (1.5 } \\
\text { L) }(\mathrm{H})\end{array}$ & 0,5 & 1480,5 & 1481 & 1480,5 & 1482,5 & 1,5 & 0 \\
\hline $\begin{array}{l}\text { Bottle Pressing } \\
(600 \mathrm{ml})(\mathrm{I})\end{array}$ & 0,8 & 1480,5 & 1481,3 & 1480,5 & 1482 & 0,7 & 0 \\
\hline Gallon Pressing (J) & 1 & 1480,5 & 1481,5 & 1480,5 & 1481,5 & 0 & $\left.0^{*}\right)$ \\
\hline $\begin{array}{l}\text { Cardboard Cup } \\
\text { Packing }(\mathrm{K})\end{array}$ & 0,5 & 1480,8 & 1483,5 & 1480,8 & 1483,5 & 2,2 & 2,2 \\
\hline $\begin{array}{l}\text { Cardboard Bottles } \\
\text { Packing }(1.5 \text { L) (L) }\end{array}$ & 1 & 1481 & 1483,5 & 1482,5 & 1483,5 & 1,5 & 1,5 \\
\hline $\begin{array}{l}\text { Cardboard Bottles } \\
\text { Packing }(600 \mathrm{ml})(\mathrm{M})\end{array}$ & 1,5 & 1481,3 & 1483,5 & 1482 & 1483,5 & 0,7 & 0,7 \\
\hline Gallons Packing (N) & 1481,5 & 1481,5 & 1483,5 & 1481,5 & 1483,5 & 0 & $\left.0^{*}\right)$ \\
\hline $\begin{array}{l}\left.{ }^{*}\right) \text { Critical Activity } \\
\text { Total Float }(S)=\text { LF - } \\
\text { ES - Duration } \\
\text { Free Float }(S F)=\text { EF - } \\
\text { ES - Duration }\end{array}$ & & & & & & & \\
\hline
\end{tabular}

\section{E. CONCLUSION AND SUGGESTION}

Based on the discussion regarding the results of research regarding the optimization of AETA product networks in PDAM Tirta Taman Sari, Madiun City, it was known that the production of AMDK AETA can be optimal if sterilization is carried out in conjunction with filtration. This is because if the two activities are done together, it will save more time in production. AETA PDAM Madiun City has several products, namely cups, $250 \mathrm{ml}$ bottles, 1 litre and also gallon bottled water. After being analyzed using the CPM network, the 
product that has the optimal time during the production process is the gallon product. This is because gallons do not need to be packed into cardboard boxes like cups and bottles.

Further researches are expected to be improved in relation to the application of networks to fuzzybased scheduling. This is because by making a time map, the total float (total elasticity) will be utilized so that non-critical activities can be optimized.

\section{ACKNOWLEDGEMENTS}

The author would like to thank all employees and staff of PDAM Tirta Taman Sari, Madiun City for their assistance so that this research can run well.

\section{REFERENCES}

Ahmed, F. (2018). Impact Of Critical Path Method (CPM) of Scheduling on On-Time Completion of Transportation Projects. University of South Carolina.

Chen, K., Si, J., Zhou, F., Zhang, R., Shao, H., \& Zhao, H. (2015). Optimization of air quantity regulation in mine ventilation networks using the improved differential evolution algorithm and critical path method. International Journal of Mining Science and Technology, 25(1), 79-84.

Chen, S.-P. (2007). Analysis of Critical Paths in a Project Network with Fuzzy Activity Times. European Journal of Operational Research, 183(1), 442-459.

Hunter, P. R., MacDonald, A. M., \& Carter, R. C. (2010). Water Supply and Health. PLoS Medicine, 7(11), 1-10.

Jéquier, E., \& Constant, F. (2010). Water as an Essential Nutrient: The Physiological Basis of Hydration. European Journal of Clinical Nutrition, 64(2), 115-123.

Kopanos, G. M., Kyriakidis, T. S., \& Georgiadis, M. C. (2014). New Continuous-Time and Discrete-Time Mathematical Formulation for Resource-Constrained Project Scheduling Problems. Computers and Chemical Engineering, 68(2), 96-106.

Kyriakidis, T. S., Kopanos, G. M., \& Georgiadis, M. C. (2012). MILP Formulations for Single- and Multi-Mode ResourceConstrained Project Scheduling Problems. Computers and Chemical Engineering, 36(1), 369-385.

Mazlum, M., \& Güneri, A. F. (2015). CPM, PERT and Project Management with Fuzzy Logic Technique and Implementation on a Business. Procedia - Social and Behavioral Sciences, 210(1/2), 348-357.

Nagata, M. F., Manginelli, W. A., Lowe, J. S., \& Trauner, T. J. (2018). Delay Analysis Using Critical Path Method Schedules. In Construction Delays.

Nicholas, J. M., \& Steyn, H. (2020). Project Management for Engineering, Business and Technology. In Project Management for Engineering, Business and Technology. Routledge.

Pankaj, R. D., Kumar, A., \& Agarwal, R. (2020). Energy Efficient Path Determination in Wireless Sensor Network by Critical Path Method. Malaya Journal of Matematik, 8(3), 797-802.

Sahoo, R. R., \& Ray, M. (2020). PSO Based Test Case Generation for Critical Path Using Improved Combined Fitness Function. Journal of King Saud University - Computer and Information Sciences, 32(4), 479-490.

Shankar, N., Sireesha, V., \& Rao, P. (2010). An Analytical Method for Finding Critical Path in a Fuzzy Project Network. International Journal of Contemp Math Science, 5(20), 953-962.

Susana, T. (2003). Air Sebagai Sumber Kehidupan. Oseana, 28(3), 17-25.

Takakura, Y., Yajima, T., Kawajiri, Y., \& Hashizume, S. (2019). Application of Critical Path Method to Stochastic Processes with Historical Operation Data. Chemical Engineering Research and Design, 149(1/2), 195-208.

Ubar, R., Kostin, S., Jenihhin, M., Raik, J., \& Jürimägi, L. (2018). Fast Identification of True Critical Paths in Sequential Circuits. Microelectronics Reliability, 81(2), 252-261.

Wang, J., Wu, J., Wu, J., Yang, Y., Xiong, Z., Niu, Y., ... Hughes, D. (2005). Critical Path. PEI Power Engineering International, 13(6), 105-111.

Zareei, S. (2018). Project Scheduling for Constructing Biogas Plant Using Critical Path Method. Renewable and Sustainable Energy Reviews, 81(1), 756-759. 
18 | Jurnal Varian| Vol. 4, No. 1, Oktober 2020, Hal. 11-18 